\title{
Effects of various types of stress on the metabolism of reserve carbohydrates in Saccharomyces cerevisiae: genetic evidence for a stress-induced recycling of glycogen and trehalose
}

\author{
Jean Luc Parrou, Marie-Ange Teste and Jean François \\ Author for correspondence: Jean François. Tel: +33561559492. Fax: +33 561559400. \\ e-mail: fran_jm@insatlse.insa-tlse.fr
}

Centre de Bioingenierie Gilbert Durand, UMR CNRS 5504, Laboratoire Associé INRA, Complexe

Scientifique de Rangeuil, 31077 Toulouse Cedex 04, France
It is well known that glycogen and trehalose accumulate in yeast under nutrient starvation or entering into the stationary phase of growth, and that high levels of trehalose are found in heat-shocked cells. However, effects of various types of stress on trehalose, and especially on glycogen, are poorly documented. Taking into account that almost all genes encoding the enzymes involved in the metabolism of these two reserve carbohydrates contain between one and several copies of the stress-responsive element (STRE), an investigation was made of the possibility of a link between the potential transcriptional induction of these genes and the accumulation of glycogen and trehalose under different stress conditions. Using transcriptional fusions, it was found that all these genes were induced in a similar fashion, although to various extents, by temperature, osmotic and oxidative stresses. Experiments performed with an msn2/msn4 double mutant proved that the transcriptional induction of the genes encoding glycogen synthase (GSY2) and trehalose-6phosphate synthase (TPS1) was needed for the small increase in glycogen and trehalose upon exposure to a mild heat stress and salt shock. However, the extent of transcriptional activation of these genes upon stresses in wild-type strains was not correlated with a proportional rise in either glycogen or trehalose. The major explanation for this lack of correlation comes from the fact that genes encoding the enzymes of the biosynthetic and of the biodegradative pathways were almost equally induced. Hence, trehalose and glycogen accumulated to much higher levels in cells lacking neutral trehalase or glycogen phosphorylase exposed to stress conditions, which suggested that one of the major effects of stress in yeast is to induce a wasteful expenditure of energy by increasing the recycling of these molecules. We also found that transcriptional induction of STRE-controlled genes was abolished at temperatures above $40{ }^{\circ} \mathrm{C}$, while induction was still observed for a heat-shockelement-regulated gene. Remarkably, trehalose accumulated to very high levels under this condition. This can be explained by a stimulation of trehalose synthase and inhibition of trehalase by high temperature.

Keywords: Saccharomyces cerevisiae, stress response, trehalose, glycogen, transcriptional regulation

\section{INTRODUCTION}

Glycogen and trehalose are the two major reserve

Abbreviations: STRE, stress-responsive element; HSE, heat-shock element. carbohydrates in the yeast Saccharomyces cerevisiae and can represent up to $25 \%$ of the dry cell mass, depending on the environmental conditions (Lillie \& Pringle, 1980). Most of the genes encoding enzymes involved in the biosynthesis and biodegradation of these two com- 
pounds have been characterized over the last five years (reviewed by François et al., 1997). Glycogen synthesis starts with an initiator protein encoded by GLG1 and GLG2 (Cheng et al., 1995), which catalyses the formation of an $\alpha(1,4)$ glucosyl primer from UDP-glucose. Elongation of this primer proceeds with glycogen synthase, which exists in two isoforms, encoded by GSY1 and GSY2 (Farkas et al., 1991), and a branching enzyme encoded by GLC3 (Thon et al., 1992; Rowen $e$ t al., 1992), which introduces the $\alpha(1,6)$ branches on the mature glycogen. Gac1p has been identified as a component of the protein-phosphatase complex which specifically activates glycogen synthase by dephosphorylation (François et al., 1992). The breakdown of glycogen into Glc1P and free glucose occurs by the combined action of a glycogen phosphorylase encoded by GPH1 (Hwang et al., 1989), and a debranching enzyme carrying transferase/glucosidase activities (Tabata \& Hizukuri, 1992). Trehalose is synthesized from UDP-glucose and Glc6P in a two-step reaction involving a trehalose-6-phosphate synthase (Tre6P synthase) encoded by TPS1 (Bell et al., 1992; Vuorio et al., 1993) and a trehalose-6-phosphate phosphatase (Tre6P phosphatase) encoded by TPS2 (De Virgilio et al., 1993). The two enzymic activities are borne by a multicomplex protein which contains a third component, encoded by TSL1, with no obvious enzymic activity (Vuorio et al., 1993). The hydrolysis of trehalose into glucose can be carried out by a neutral cytosolic trehalase encoded by NTH1 (Kopp et al., 1993), or by an acid-vacuolar trehalase encoded by ATH1 (Destruelle $e t$ al., 1995; Alizadeh \& Klionsky, 1996).

The expression of genes involved in glycogen and trehalose metabolism in response to adverse environmental conditions has been partially documented. Notably, it has been shown that mRNAs corresponding to NTH1 and TPS2 increased during a heat shock from 30 to $40{ }^{\circ} \mathrm{C}$ (Nwaka et al., 1995; De Virgilio et al., 1993) and that TPS2 and GAC1 transcripts were induced upon osmotic stress (Gounalaki \& Thireos, 1994; Schüller et al., 1994). Bell et al. (1992) also showed, by Western blot analysis, that the TPS1 gene product increased when yeast cells were shifted from 27 to $40^{\circ} \mathrm{C}$. Ni \& Laporte (1995) reported a five- to tenfold induction of $\beta$ galactosidase activity expressed from a GSY2-lacZ gene fusion after a temperature shift from 23 to $37^{\circ} \mathrm{C}$. Furthermore, induction of GSY2 by heat shock, and TPS2 by osmotic shock, were shown to be dependent on the presence of a stress-responsive element (STRE; core consensus CCCCT) in the promoter of these two genes (Ni \& Laporte, 1995; Gounalaki \& Thireos, 1994). This element has been demonstrated to be essential for the response of other STRE-regulated genes such as DDR2, CTT1 and HSP12 (reviewed by Ruis \& Schüller, 1995), and since all the genes involved in glycogen and trehalose metabolism contain between one and several copies of the STRE in their promoter (Varela et al., 1995), these genes may be affected by a much broader range of stress conditions. In addition, their transcriptional induction could require Msn2p and Msn4p transcriptional factors, as has been shown recently for some stress-responsive genes (Martinez-Pastor et al., 1996).

Looking for a physiological role of STREs present in the promoter of genes involved in glycogen and trehalose metabolism, we investigated the transcriptional activation of these genes and the metabolic consequences with respect to glycogen and trehalose accumulation in response to various types of stress.

\section{METHODS}

Yeast strains and culture conditions. Yeast strains used in this study are listed in Table 1 . Unless otherwise stated, stress experiments were carried out with strains growing on complete YPD medium $[2 \%(\mathrm{w} / \mathrm{v})$ glucose, $1 \%(\mathrm{w} / \mathrm{v})$ bactopeptone and $1 \%(\mathrm{w} / \mathrm{v})$ yeast extract] at $30^{\circ} \mathrm{C}$ to midexponential phase $\left(\mathrm{OD}_{600} 0.4\right.$ and not higher than 0.6 to avoid the early activation of transcription of glycogen and trehalose genes). For strains transformed with episomal vectors, we used YNB medium $[0 \cdot 17 \%(\mathrm{w} / \mathrm{v})$ yeast nitrogen base without ammonium sulfate and amino acids, $0 \cdot 1 \%(\mathrm{w} / \mathrm{v})$ ammonium sulfate] supplemented with carbon source at a final concentration of $2 \%(\mathrm{w} / \mathrm{v})$ and the appropriate auxotrophic requirements. Stress was induced by addition to the yeast culture of either a tenfold concentrated solution of $\mathrm{NaCl}$ (final concentration $0.3 \mathrm{M}$ ) or sorbitol (final concentration $0.4 \mathrm{M}$ ), a 1000 -fold concentrated solution of $\mathrm{H}_{2} \mathrm{O}_{2}$ (final concentration $0.4 \mathrm{mM}$ ) or a 100 -fold concentrated solution of benzoate made in ethanol (final concentration $5 \mathrm{mM}$ ). In heat-shock experiments, and unless otherwise stated, cells were grown at $25^{\circ} \mathrm{C}$ and then shifted to a higher temperature in temperaturecontrolled water baths. It was checked that the cultures $(50 \mathrm{ml}$ in $500 \mathrm{ml}$ flasks) reached the water bath temperature in less than 2 min.

Construction of gene fusions. The episomal and integrative vectors from Myers et al. (1986) were used to generate the lacZ gene fusions (Table 2 ). The promoters from glycogen metabolism genes were cloned in-frame with the lac $Z$ gene using PCR-amplified products obtained from the pairs of primers listed in the table. This methodology allowed the introduction of BamHI and PstI restriction sites to the $5^{\prime}$ and $3^{\prime}$ ends of the amplified fragments. The length of the sequence upstream to the translation initiation site was 693 bp for GSY2, 694 bp for GAC1 and 406 bp for GPH1. The lacZ gene was fused to the sixth codon of each of the genes. pJL 5 was further sequenced to confirm the fidelity of the amplification reaction. With respect to trehalose metabolism genes, the strategy for generating the transcriptional fusions was slightly different (see Table 2). The promoters were cut from their respective loci using appropriate restriction enzymes and inserted inframe with lac $Z$ using the vectors described by Myers $e t$ al. (1986). The length of the sequence upstream to the translation initiation site was about $1 \mathrm{~kb}$ for TPS1 and 770 bp for NTH1. pW204A-236 bearing the SSA3-lacZ gene fusion (Boorstein \& Craig, 1990) was kindly provided by E. Craig (University Wisconsin, Madison, USA).

Chromosome integration of gene fusions. All constructs were digested with $\mathrm{NcoI}$ and integrated at the URA3 locus of the genome according to the targeted integration method described by Orr-Weaver et al. (1983). Unless otherwise stated, the diploid strain JF326 was used as the recipient for transformation, which was carried out using the modified 
Table 1. Yeast strains

\begin{tabular}{|c|c|c|c|}
\hline Yeast strain & $\begin{array}{c}\text { Mating } \\
\text { type }\end{array}$ & Genotype & Source* \\
\hline KT 1112 & a & leu2- $\Delta 1$ ura3-52 his $3-\Delta 200$ & K. Tatchell ${ }^{1}$ \\
\hline JF 326 & $a / \alpha$ & leu $2-\Delta 1 /$ leu $2-\Delta 1$ ura3-52/ura3-52 his $3-\Delta 200 /$ his $3-\Delta 200$ & J. François \\
\hline W $303-1 \mathrm{~A}$ & a & leu2-3,112 ura3-1 his3-11,15 trp1-1 ade2-1 can $1-100$ & R. Rothstein ${ }^{2}$ \\
\hline $\mathrm{W} m \mathrm{mnn} 2 \mathrm{msn} 4$ & a & leu 2 ura 3 his 3 trp 1 ade 2 can 1 msn2-- $3::$ HIS 3 msn $4-1::$ TRP1 & F. Estruch ${ }^{3}$ \\
\hline PH3-6A & a & leu 2 ura 3 bis $3 / 4$ trp 1 GPH 1 & P. Hwang ${ }^{4}$ \\
\hline PH3-6B & a & leu 2 ura 3 his $3 / 4$ trp1 gph1 $1:: L E U 2$ & P. Hwang \\
\hline YS18 & a & his $3-11,15$ leu2-3,112 ura3- $\Delta 5$ can1 gal NTH1 & H. Holzer ${ }^{5}$ \\
\hline YSN1 & a & 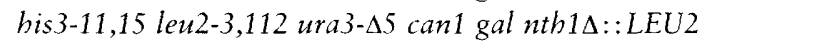 & H. Holzer \\
\hline \multicolumn{4}{|c|}{ KT 1112 background } \\
\hline JLP 5-1A & a & leu2 bis3 URA3:: GSY2-lacZ & This study \\
\hline JLP 44-8A & a & leu2 bis3 URA3:: GPH1-lacZ & This study \\
\hline JLP 51-3D & a & leu2 his 3 URA3:: GAC1-lacZ & This study \\
\hline JLP 87-8A & a & len2 bis 3 URA3:: TPS1-lacZ & This study \\
\hline \multicolumn{4}{|c|}{ W303-1A background } \\
\hline JLP 1-1D & a & leu2 his3 trp1 ade 2 can1 URA3:: GSY2-lacZ & This study \\
\hline JF901 & a & leu2 his 3 trp1 ade 2 can1 URA3:: TPS1-lacZ & This study \\
\hline $11 \mathrm{a} 1-1 \mathrm{~A}$ & $\mathrm{a}$ & leu 2 his 3 trp 1 ade 2 ade 8 URA3::CTT1-lacZ & K. Tatchell \\
\hline JF843 & a & $\begin{array}{l}\text { leu2 his } 3 \text { trp1 ade } 2 \text { can } 1 \text { msn2- } \triangle 3:: H I S 3 \text { msn4-1:: TRP1 } \\
\text { URA3:: GSY2-lacZ }\end{array}$ & This study \\
\hline JF900 & a & $\begin{array}{l}\text { leu2 his } 3 \text { trp1 ade } 2 \text { can } 1 \text { msn2- } \triangle 3:: H I S 3 \text { msn } 4-1:: T R P 1 \\
\text { URA3::TPS1-lacZ }\end{array}$ & This study \\
\hline
\end{tabular}

"1, Louisiana State University Medical Center, Shreveport, USA ; 2, UMDNJ-New Jersey Medical School, Newark, USA; 3, Universitad de Valencia, Burjassot, Spain; 4, University of California, San Francisco, USA; 5, University of Freiburg, Freiburg, Germany.

Table 2. Plasmids

\begin{tabular}{|c|c|c|}
\hline Plasmid & Description & Source* \\
\hline YEp356 & $2 \mu \mathrm{m} U R A 3$ episomic vector & A. M. Myers ${ }^{1}$ \\
\hline YIp356 & URA3 integrative vector & A. M. Myers \\
\hline pGSY2 & GSY2 & T. Hardy ${ }^{2}$ \\
\hline pST93 & GAC1 & J. François \\
\hline YCP50::GPH1 & GPH1 & P. Hwang \\
\hline pMB12 & TPS1 & M. I. Gonzalez ${ }^{3}$ \\
\hline pNTH1 & NTH1 & M. Kopp ${ }^{4}$ \\
\hline pJL5 & YIp356, GSY2-lacZ; PCR amplification fragment from pGSY2 into YIp356 $(B / P)$ & This study \\
\hline pJL26 & YIp356, GAC1-lacZ; PCR amplification fragment from pST93 into YIp356 $(B / P)$ & This study \\
\hline pJL16 & YIp356, GPH1-lacZ; PCR amplification fragment from YCP50:: GPH1 into YIp356 $(B / P)$ & This study \\
\hline pSL1 & YEp356R, TPS1-lacZ; $1.8 \mathrm{~kb}$ restriction fragment from $\mathrm{pMB} 12$ into YEp356R $(H / S)$ & M. A. Blazquez 5 \\
\hline pJL28 & YIp356R, TPS1-lacZ; $1.8 \mathrm{~kb}$ restriction fragment from pSL1 into YIp356R $(H / S)$ & This study \\
\hline pNL1 & YEp353, NTH1-lacZ; 1.3 kb restriction fragment from pNTH1 into YEp353 $(S / H\rangle$ & M. A. Blazquez \\
\hline pWB2044-236 & pHT202, SSA3-lacZ (centromeric vector) & W. R. Boorstein ${ }^{6}$ \\
\hline Locus & Primers for amplification of promoters & \\
\hline \multirow[t]{2}{*}{ GSY2 } & $5^{\prime}$-CCGGGGATCCAGATTGCAGGCGTAG(-679)-3' & \\
\hline & $3^{\prime}(+4)$ AGGGCACTGGATGTTTGACGTCCGTA $5^{\prime}$ & \\
\hline \multirow[t]{2}{*}{ GAC1 } & $5^{\prime}$-CCGGGGATCCCTGCAGCAGAGTGGG $(-680)-3^{\prime}$ & \\
\hline & $3^{\prime}(+4)$ TATGTTTGACGATGATGACGTCCGTA $5^{\prime}$ & \\
\hline \multirow[t]{2}{*}{ GPH1 } & $5^{\prime}$-CCGGGGATCCGTCGACGAAATAAGT $(-392)-3^{\prime}$ & \\
\hline & $3^{\prime}(+4)$ TATTGGCTTCTTGGATGACGTCCGTA $5^{\prime}$ & \\
\hline
\end{tabular}

*1, Iowa State University, Ames, USA ; 2, Indiana University School of Medicine, Indianapolis, USA ; 3 and 5, CSIC, UAM, Madrid, Spain; 4, University of Freiburg, Freiburg, Germany; 6, University of Wisconsin, Madison, USA. 
lithium acetate method (Schiestl \& Gietz, 1989). The transformants were selected for URA3 prototrophy and lacZ expression. Correct integration at the URA3 locus was verified by Southern blot analysis for a few of the transformants. Haploid segregants were obtained using the standard yeast genetic procedure for sporulation and tetrad analysis (Rose $e t$ al., 1990).

Enzyme assays. Cell samples for $\beta$-galactosidase assay (about $2-5 \times 10^{8}$ cells) were collected by centrifugation $(3800 \mathrm{~g}$ for $6 \mathrm{~min}$ ), washed once with $1 \mathrm{ml}$ cold water and the pellet was immediately frozen at $-20^{\circ} \mathrm{C}$. Crude extract was prepared according to Rose \& Botstein (1983) with the following modifications. The frozen pellets were resuspended in $500 \mu \mathrm{l}$ breaking $\mathrm{Z}$ buffer in glass tubes in the presence of $1 \mathrm{~g}$ glass beads $(0.5 \mathrm{~mm}$ diameter $)$. The tubes were vortexed four times at top speed in $30 \mathrm{~s}$ bursts, being chilled on ice between bursts. The extracts were clarified by centrifugation $(1000 \mathrm{~g}$ for $10 \mathrm{~min}$ ) and the supernatants were used for the enzyme assay and protein determination (Bradford, 1976) using BSA as a standard. Cell sampling, preparation of crude extracts and assays of glycogen synthase were carried out as described previously (François et al., 1988). Tre6P synthase activity was assayed at $42{ }^{\circ} \mathrm{C}$ according to the non-radioactive method described by Vandercammen et al. (1989).

Determination of glycogen and trehalose contents. The procedures described previously for the determination of glycogen and trehalose (Becker, 1978; Vandercammen et al., 1989) were used with the following modifications. The cell pellet (obtained as for $\beta$-galactosidase assay) was resuspended in $250 \mu \mathrm{l} 0.25 \mathrm{M} \mathrm{Na}_{2} \mathrm{CO}_{3}$ and heated at $95^{\circ} \mathrm{C}$ for $2 \mathrm{~h}$ with occasional stirring. The suspension was adjusted to $\mathrm{pH} 5 \cdot 2$ with $150 \mu \mathrm{l} 1 \mathrm{M}$ acetic acid and $600 \mu \mathrm{l} 0 \cdot 2 \mathrm{M}$ sodium acetate buffer $\mathrm{pH} 5 \cdot 2$. Half of this mixture was incubated overnight at $57^{\circ} \mathrm{C}$ with continuous shaking on a rotary shaker in the presence of $100 \mu \mathrm{g}$ of $\alpha$-amyloglucosidase from Aspergillus niger (Boehringer, 208464), freshly prepared as a $10 \mathrm{mg} \mathrm{ml}^{-1}$ stock solution made in $0 \cdot 2 \mathrm{M}$ sodium acetate buffer $\mathrm{pH} 5 \cdot 2$. Incubation at this temperature was found to be optimal for complete glycogen degradation and inhibition of endogenous trehalase which contaminated the amyloglucosidase. The second half of the mixture was incubated overnight at $37^{\circ} \mathrm{C}$ in the presence of $3 \mathrm{mU}$ trehalase (Sigma, T8778, 0.25 $\mathrm{U} \mathrm{ml}^{-1}$ ). The glucose liberated was determined with the glucose oxidase reagent (Sigma, kit 510-A).

Western blot analysis. Total proteins were extracted from $1 \mathrm{ml}$ of exponential-phase culture which was mixed with $150 \mu \mathrm{l}$ of a solution containing $1.85 \mathrm{M} \mathrm{NaOH}$ and $7 \cdot 4 \% \beta$ mercaptoethanol, and incubated on ice for $10 \mathrm{~min}$. Proteins were precipitated by the addition of $300 \mu 150 \%$ TCA. The mixture was mixed by inversion and incubated on ice for $2 \mathrm{~h}$ before centrifugation ( $3 \mathrm{~min}, 13000$ r.p.m.). The pellet was washed with $1.2 \mathrm{ml}$ cold acetone, dried under vacuum in a Speedvac and resuspended in $40 \mu \mathrm{l} 0 \cdot 1 \mathrm{M} \mathrm{NaOH}$.

Proteins $(40 \mu \mathrm{g}$, as determined by Bradford essay) were separated by electrophoresis on a $10 \%$ SDS-polyacrylamide gel and transferred to nylon membranes (Hybond-C, Amersham). Proteins were further probed with a 1:10000 dilution of primary antibody $\mathrm{KH}-1142$ raised against the $56 \mathrm{kDa}$ subunit of Tre6P synthase (a gift from J. Londesborough) and a 1:3000 dilution of horseradish peroxidase-anti rabbit secondary antibody, according to the ECL Western blotting protocols (Amersham).

\section{RESULTS}

\section{Stress-inducibility of genes encoding glycogen and trehalose metabolic enzymes and effect of $m s n$ mutations}

In order to investigate the quantitative response of genes encoding enzymes of glycogen and trehalose metabolic pathways to various stress conditions, we used strains with chromosomally integrated promoter-lacZ fusions (Table 1). The stress-inducibility of these genes was compared with those of CTT1, a well-characterized stress-responsive gene (Schüller et al., 1994). The values of $\beta$-galactosidase reported in Fig. 1 are those obtained after $1 \mathrm{~h}$ incubation under the different stress conditions since the kinetics of induction showed that the level of expression of these genes reached a maximum within this period of incubation. In response to various stresses, glycogen and trehalose genes displayed the same induction pattern. The induction factor ranged from fiveto sevenfold for the temperature shift to $37^{\circ} \mathrm{C}$, to twoto threefold for the osmotic shock with $0.3 \mathrm{M} \mathrm{NaCl}$. In contrast, treatment with $0.4 \mathrm{M}$ sorbitol, and oxidative stresses carried out with $0.4 \mathrm{mM} \mathrm{H_{2 }} \mathrm{O}_{2}$ or $5 \mathrm{mM}$ benzoate, caused a weak but definite induction of genes. At higher concentrations (up to $1.5 \mathrm{M} \mathrm{NaCl}$ or up to $5 \mathrm{mM} \mathrm{H}_{2} \mathrm{O}_{2}$ ), the induction of these genes was much lower, or even abolished. Stress responses were also tested with the NTH1 gene, encoding neutral trehalase. Using, in this case, a multicopy plasmid bearing the NTH1 promoter fused to lacZ, a two- to threefold induction of $\beta$-galactosidase activity was measured after $1 \mathrm{~h}$ incubation at $37^{\circ} \mathrm{C}$ or after exposure of cells to $0.3 \mathrm{M} \mathrm{NaCl}$ (results not shown). These results were comparable to those obtained with integrated lac $Z$ fusions.

We then verified that the induction of TPS1 was actually accompanied by changes in the amount of its product, Tps1p, using the antibody $\mathrm{KH}-1142$ raised against this polypeptide (Vuorio et al., 1993). The increase in the intensity of the immunoreactive $56 \mathrm{kDa}$ band corresponding to $\mathrm{Tps} 1 \mathrm{p}$ in cells exposed to the various stresses (Fig. 2a, b) correlated fairly well with the $\beta$ galactosidase induction from the TPS1-lacZ gene fusion. The most surprising result was obtained upon treatment of the cells with $\mathrm{H}_{2} \mathrm{O}_{2}$. We found a net increase in the amount of protein in the $56 \mathrm{kDa}$ band during the $1 \mathrm{~h}$ incubation, while the transcriptional activation of TPS1 as measured from the lac $Z$ fusion gene was barely detectable (see Fig. 1). We do not have any explanation for this discrepancy. However, this result is consistent with the observation of Schüller $e t$ al. (1994), who reported that GAC1 mRNA was also induced in response to oxidative stress, but to a lesser extent than osmotic shock. The strong intensity of the signal observed in the control culture after $150 \mathrm{~min}$ incubation is likely to have resulted from TPS1 induction at the end of the exponential growth on glucose (J. L. Parrou \& J. François, unpublished data).

The stress response pattern of the CTT1-lacZ gene fusion was clearly different from that found for genes 


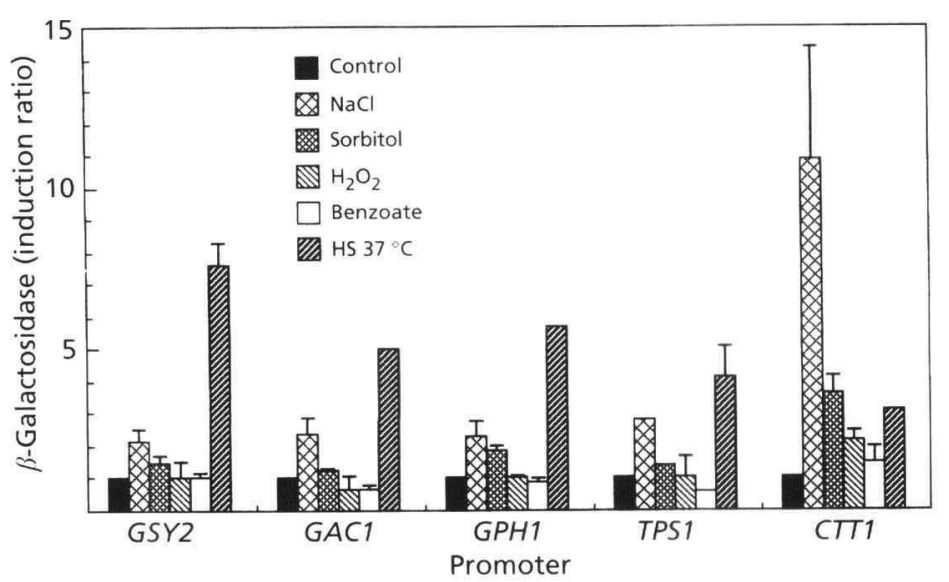

Fig. 1. Induction of lacZ fusions by osmotic, oxidative and heat stresses. Promoter-lac $Z$ gene fusions were integrated in strain KT1112 (GSY2, GAC1, GPH1 and TPS1) or strain W303-1A (CTT1). Exponential-phase cells growing on glucose were subjected to various stress conditions as described in Methods. Induction ratios were calculated by dividing the activity of $\beta$-galactosidase [nmol min $^{-1}$ (mg protein) ${ }^{-1}$ ] measured in stressed cells by the activity measured in the control cells after $1 \mathrm{~h}$ incubation. Absolute values \pm SEM for the control were $5 \cdot 7 \pm 2 \cdot 9$ (GSY2), $1.3 \pm 0.1$ (GAC1), 18.5 \pm 3.5 (GPH1), $17.5 \pm 1.6$ (TPS1) and $1.6 \pm 0.4$ (CTT1) (three different experiments). (a)

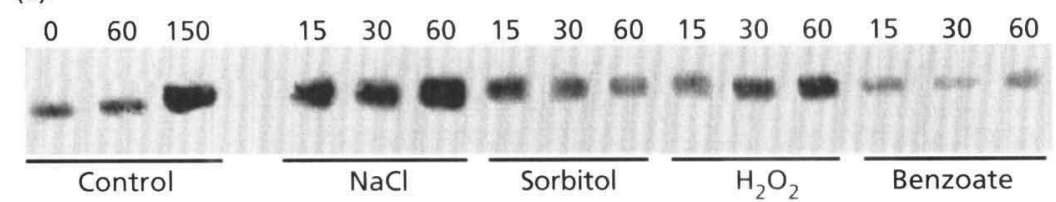

(b)

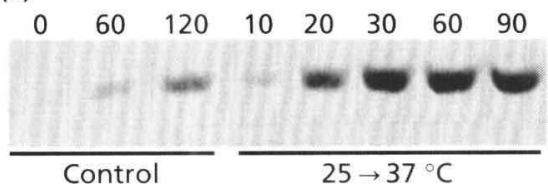

Fig. 2. Stress-induced accumulation of the $56 \mathrm{kDa}$ subunit of Tre6P synthase in a wildtype strain. Strain JLP5-1A growing exponentially on YPD medium at $25^{\circ} \mathrm{C}$ was subjected to osmotic and oxidative stresses (a) or to a temperature upshift to $37^{\circ} \mathrm{C}$ (b). Samples were harvested at the indicated times and treated as described in Methods. involved in glycogen and trehalose metabolisms. In particular, these genes were much less sensitive to osmotic and oxidative stresses than CTT1 (see also Schüller et al., 1994; Martinez-Pastor et al., 1996). This difference in sensitivity between CTT1 and GSY2 was apparently strain-independent since similar results to those shown in Fig. 1 were obtained when the GSY2-lacZ gene fusion was integrated into the genome of W303-1A. Schüller et al. (1994) showed that expression of CTT1 was abolished under osmotic shock in mutants defective in HOG1 or PBS2 genes encoding components of the high-osmolarity-glycerol signalling pathway. These authors also showed that GAC1 mRNA was reduced in these mutants; consistent with this latter result, we also found a reduced induction of the other glycogen and trehalose genes in a hog 1 mutant exposed to $0 \cdot 3 \mathrm{M} \mathrm{NaCl}$ (data not shown).

Because MSN2 and MSN4 are required for transcriptional activation of STRE-regulated genes such as HSP12, CTT1 or DDR2 (Martinez-Pastor et al., 1996), we investigated the expression of GSY2 and TPS1 in an $m s n 2 / m s n 4$ double mutant exposed to a mild heat stress and an osmotic shock. We found that the basal expression of these two genes, as estimated by lac $Z$ fusions, was two- to threefold lower than in a wild-type strain. Upon a temperature shift to $37^{\circ} \mathrm{C}$ and an osmotic stress, the transcriptional activation was completely abolished in this mutant (result not shown).
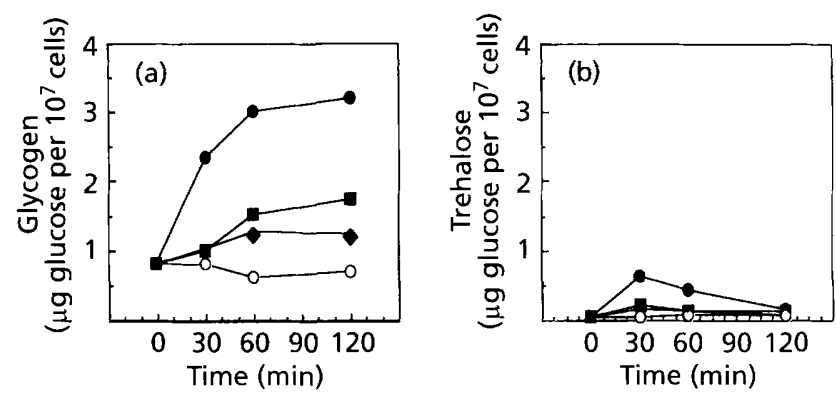

Fig. 3. Effects of heat, osmotic and oxidative stresses on glycogen and trehalose levels in a wild-type strain. Glycogen (a) and trehalose (b) in control condition (O), temperature shift from 25 to $37^{\circ} \mathrm{C}(\mathrm{O})$ and challenge with $0.3 \mathrm{M} \mathrm{NaCl}$ ( $\square$ ) or $0.4 \mathrm{mM} \mathrm{H}_{2} \mathrm{O}_{2}(\bullet)$ in JLP5-1A strain.

\section{Effects of stress on glycogen and trehalose contents in wild-type and $m s n 2 / m s n 4$ double mutant strains}

As shown in Fig. 3(a), all the stress conditions tested caused a sizeable rise in glycogen content, even after treatment of yeast with $\mathrm{H}_{2} \mathrm{O}_{2}$, which did not lead to significant activation of the corresponding genes. With regard to trehalose (Fig. $3 \mathrm{~b}$ ), the rise was transient after a temperature shift from 25 to $37^{\circ} \mathrm{C}$, weak but reproducible during incubation of cells in the presence of 0.3 M NaCl as already noticed by Lewis et al. (1995), 

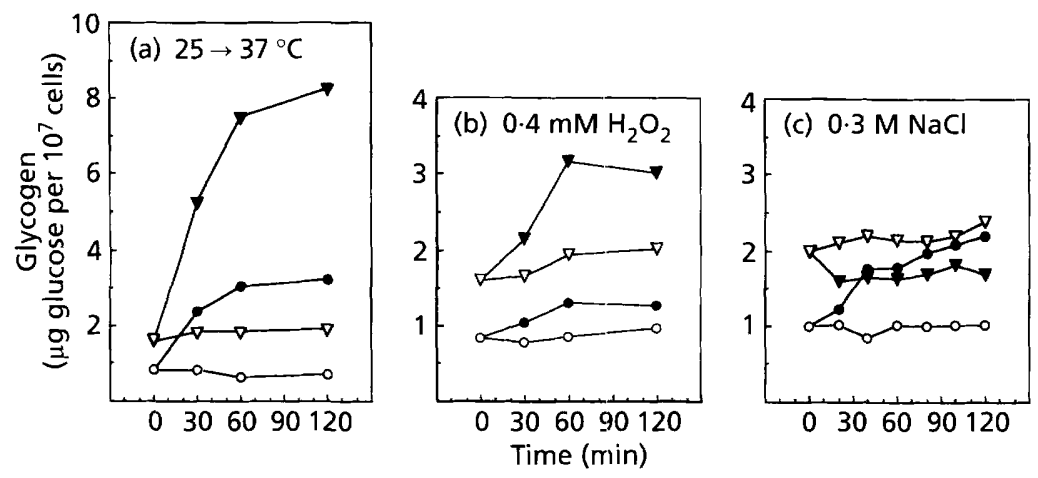

Fig. 4. Glycogen levels in a wild-type or gph1 strains exposed to various types of stress. Temperature shift from 25 to $37^{\circ} \mathrm{C}$ (a) and challenge with $0.4 \mathrm{mM} \mathrm{H}_{2} \mathrm{O}_{2}$ (b) or $0.3 \mathrm{M}$ $\mathrm{NaCl}$ (c). Open symbols are for the control condition and filled symbols for the stress experiment. Wild-type strain $\mathrm{PH} 3-6 \mathrm{~A}(0,0)$ and isogenic gph1 strain PH3-6B $(\nabla, \nabla)$.
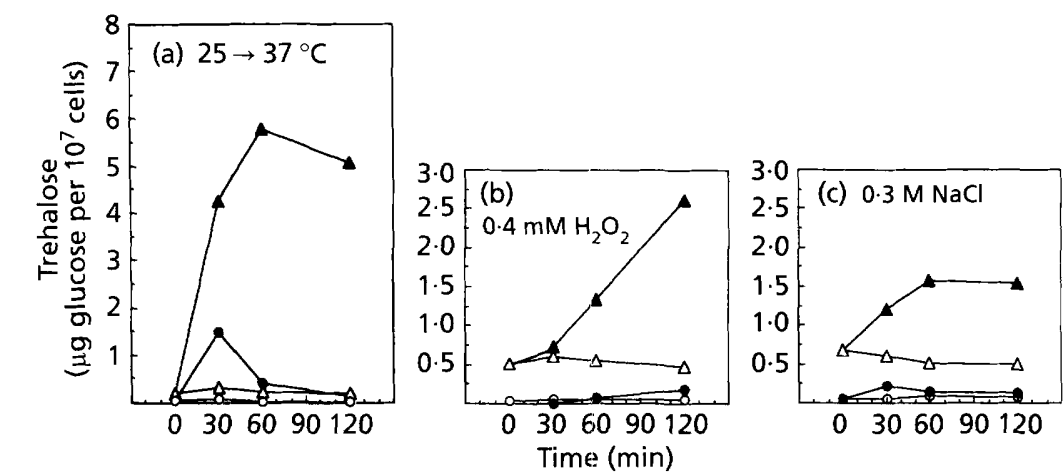

Fig. 5. Trehalose levels in a wild-type or nth1 strains exposed to various types of stress. Temperature shift from 25 to $37^{\circ} \mathrm{C}$ (a) and challenge with $0.4 \mathrm{mM} \mathrm{H}_{2} \mathrm{O}_{2}$ (b) or $0.3 \mathrm{M}$ $\mathrm{NaCl}$ (c). Open symbols are for the control condition and filled symbols for the stress experiment. Wild-type strain YS18 $(O$, and isogenic nth1 strain YSN1 $(\triangle, \mathbf{\Delta})$.

and undetectable upon exposure to oxidative agents. Mutants defective in both Msn2p and Msn4p transcriptional activators did not accumulate glycogen and trehalose under heat or osmotic shock (not illustrated).

\section{Genetic evidence for recycling of glycogen and trehalose in response to stress}

The observations that the increase in glycogen and trehalose did not correlate with the extent of GSY2 and TPS1 transcriptional induction, and that genes of synthesis and degradation were similarly induced by stress, led us to investigate the possibility of an enhanced recycling of these molecules in response to stress. This question has already been studied by Hottiger et al. (1987) for trehalose during heat shock. While these authors demonstrated a futile cycling of trehalose using pulse-chase experiments, we tested this hypothesis with a genetic approach using mutant strains defective in glycogen phosphorylase (gph1 mutant) and neutral trehalase (nth1 mutant). As it can be seen in Fig. 4(a) and 5 (a), accumulation of glycogen and trehalose was strongly enhanced in $g p h 1$ and $n t h 1$ null mutants subjected to a temperature shift to $37^{\circ} \mathrm{C}$. Furthermore, the accumulation of trehalose was sustained in the $n t h 1$ mutant, while it was transient in the wild-type (Fig. 3b). Treatment of yeast cells with $\mathrm{H}_{2} \mathrm{O}_{2}$ also caused an important increase in both glycogen and trehalose (Fig. $4 \mathrm{~b}, 5 \mathrm{~b})$. As with the heat-shock treatment, exposure of cells to $0.3 \mathrm{M} \mathrm{NaCl}$ resulted in a higher and sustained level of trehalose in a $n t h 1$ null mutant (Fig. 5c). In contrast, the accumulation of glycogen upon salt stress was abolished in a gph1 mutant (Fig. 4c).

All these experiments also showed that exponentially growing cultures of $g p h 1$ and $n t h 1$ mutants contain, respectively, two to five times higher levels of glycogen and trehalose than the isogenic wild-type strains, indicating the occurrence of a weak recycling of these molecules under normal growth conditions.

\section{Effect of the absolute temperature at which the heat shock was performed on glycogen and trehalose induction}

Since there are almost as many different temperature upshift conditions as papers dealing with heat shock, i.e. temperatures ranging from $36^{\circ} \mathrm{C}$ (Panek et al., 1990) to $45^{\circ} \mathrm{C}$ (Winkler et al., 1991), we wished to carefully investigate the effects on glycogen and trehalose metabolism of the absolute temperature at which the heat shock is performed. This experiment (Fig. 6) showed that the induction of TPS1 was seen in cells transferred to $33{ }^{\circ} \mathrm{C}$, reached a maximum of four- to fivefold at 37 to $38^{\circ} \mathrm{C}$, and then dropped precipitously to zero at temperatures above $40^{\circ} \mathrm{C}$.

The lack of transcriptional activation at $42{ }^{\circ} \mathrm{C}$ was also seen for NTH1 and CTT1 and all glycogen genes and was not strain-dependent since the same observation 


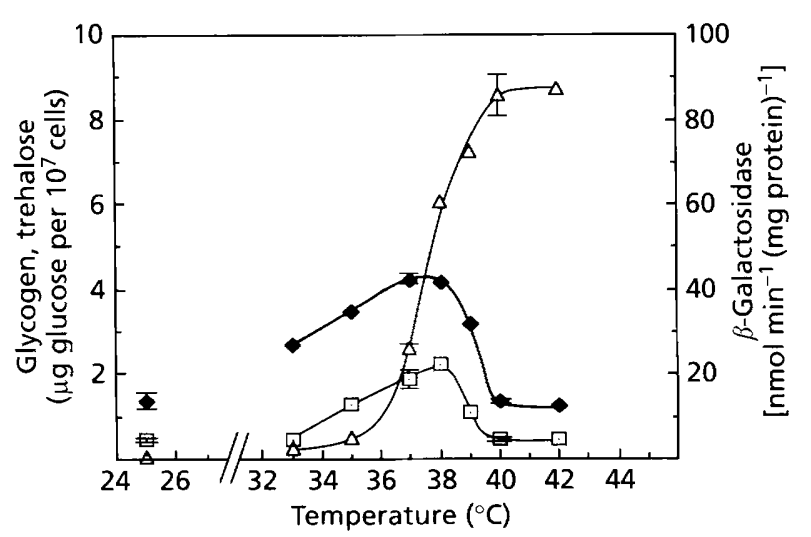

Fig. 6. Effect of the absolute temperature at which the heat shock is performed on the TSP1-lacZ gene fusion, and on the levels of glycogen and trehalose. An exponentially growing culture of strain JLP87-8A at $25^{\circ} \mathrm{C}$ was divided into portions and transferred to water baths at the indicated temperatures. Samples were taken for a $2 \mathrm{~h}$ period to obtain the kinetics of gene induction and the pattern of glycogen and trehalose accumulation. The maximal values, which were usually obtained after $1 \mathrm{~h}$ incubation, are reported, except for trehalose at low heat-shock temperatures $\left(33\right.$ to $37^{\circ} \mathrm{C}$ ). Since trehalose accumulated transiently at this temperature range, the value corresponding to the peak of accumulation was taken and reported on the figure. $\downarrow, \beta$-Galactosidase; $\square$, glycogen; $\triangle$, trehalose.

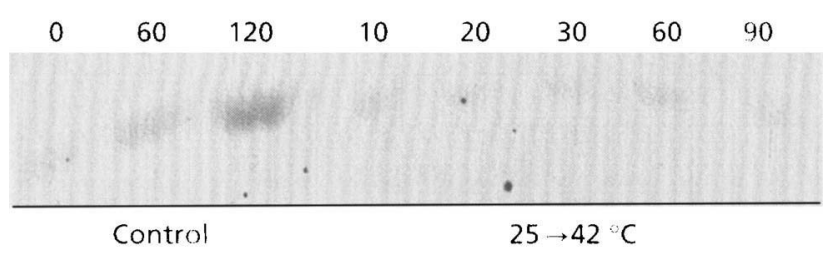

Fig. 7. Lack of induction of the small subunit of the Tre6P synthase in yeast exposed to a temperature shift from 25 to $42{ }^{\circ} \mathrm{C}$. Samples of strain JLP5-1A were harvested at the indicated times and treated, as described in Methods.

was found for the GSY2-lacZ fusion integrated in the W303-1A genome. In contrast, $\beta$-galactosidase activity from SSA3-lacZ, a typical heat-shock-element (HSE)regulated promoter, still increased threefold at this temperature (results not shown). This experiment indicated that the lack of transcriptional induction at $42{ }^{\circ} \mathrm{C}$ could not be due to the instability of $\beta$ galactosidase. We verified this by a $42{ }^{\circ} \mathrm{C}$ incubation of yeast extract containing $\beta$-galactosidase expressed from a lac $Z$ fusion, and found that the $\beta$-galactosidase activity remained unchanged over a $2 \mathrm{~h}$ period. To confim further that transcriptional induction failed at $42{ }^{\circ} \mathrm{C}$, we determined by both Western blot analysis and enzyme activity assay whether the TPS1 product was expressed. We found that there was neither increase in the signal nor change in Tre6 $P$ synthase activity during the incubation of yeast at $42^{\circ} \mathrm{C}$ (Fig. 7), whereas these two parameters drastically rose after incubation of cells at $37^{\circ} \mathrm{C}$ (see Fig. 2b).

The temperature-dependent activation of GSY2-lacZ was identical to TPS1-lacZ (not shown), and the pattern of glycogen accumulation followed that of gene induction (Fig. 6). However, the extent of glycogen accumulation and transcriptional induction did not correlate since GSY2 was induced twofold while there was no increase in glycogen at $33^{\circ} \mathrm{C}$. This lack of correlation is likely to have been due to the concomitant increase in GPH1 expression (Fig. 1), which counteracted glycogen synthesis. At temperatures above $40^{\circ} \mathrm{C}$, the lack of glycogen accumulation could be related to the defect in the transcriptional induction of GSY2 (Fig. 1) and to reduced glycogen synthase activity. We indeed found that the activity of glycogen synthase was optimal between 25 and $30^{\circ} \mathrm{C}$ and was reduced to $25 \%$ at $42{ }^{\circ} \mathrm{C}$ (data not illustrated).

In contrast to the situation with glycogen, the synthesis of trehalose in response to increased temperature did not follow the transcriptional induction of TPS1. It should be emphasized that the accumulation of trehalose in yeast incubated at temperatures ranging from 33 to $38^{\circ} \mathrm{C}$ was transient (for an example, see Fig. $3 \mathrm{~b}$ ). In this range of temperatures, the accumulation of trehalose required transcriptional induction of TPS1, since deletion of MSN2 and MSN4 abolished both gene induction and trehalose synthesis. At temperatures above $40^{\circ} \mathrm{C}$, cells accumulated huge amounts of trehalose either in wild-type strains or in the $m s n 2 / m s n 4$ double mutant. However, the accumulation of trehalose was $30 \%$ lower in this mutant strain. We also found that the accumulation of trehalose at $42{ }^{\circ} \mathrm{C}$ was enhanced twofold in a nth1 null mutant (results not shown), indicating that at this high temperature, trehalase was not completely inactive.

\section{DISCUSSION}

As detailed in other reports (Ruis \& Schüller, 1995; Varela \& Mager, 1996), stress conditions imposed on yeast can be as diverse as entry into stationary phase, nutrient starvation, high and low temperature, high and low osmolarity, high ethanol concentration and presence of heavy metals or oxidative compounds. Several similarities have already been reported for the response to these stresses and a previous exposure to one stress generally increases the acquisition of tolerance against challenge by another stress (Schüller et al., 1994; Mager \& de Kruijff, 1995; Lewis et al., 1995). Hence, it is not surprising to find convergent molecular responses and a common feature at the transcriptional level, namely the stress-responsive element (STRE), a cis-acting element with the core consensus CCCCT present in the promoter of genes known to be induced by a broad range of stressful conditions (Varela et al., 1995). Previous results with artificial promoters bearing one or more STREs in both orientations showed that the extent of gene induction was dependent upon the number of these 
motifs (Kobayashi \& McEntee, 1990; Marchler et al., 1993). Furthermore, a certain degree of synergism among different repeats within a promoter was also shown to be necessary for efficient transcriptional activation of stress-responsive genes, including DDR2 (Kobayashi \& McEntee, 1993), GSY2 (Ni \& Laporte, 1995) and HSP12 (Varela et al., 1995). Our study showed that all the genes encoding enzymes of glycogen and trehalose metabolism were induced in a similar fashion and to the same extent in response to stress, independently of the number of STREs, ranging from one (GAC1), to two (GSY2) or even six repeats (TPS1). These data agree with those of Winderickx et al. (1996) who showed a co-induction of all the genes encoding subunits of the Tre6P synthase/phosphatase complex in response to stress. It was at variance with that of CTT1 which contains three CCCCT motifs, but as for this latter gene and other STRE-responsive genes (MartinezPastor et al., 1996), the transcriptional induction of genes involved in glycogen and trehalose metabolism was lost in an $m s n 2 / m s n 4$ double mutant in response to heat and osmotic stress (results not shown). This demonstrates that the stress response of these genes is mediated by the interaction of STREs with Msn2p/ $\mathrm{Msn} 4 \mathrm{p}$ transcriptional activators. However, our results also indicated that not all STREs in the promoter of these genes contribute equally to the stress response, and that one STRE could be predominant in this response, as has been shown previously for HSP12 (Varela et al., 1995) and for GSY2 (Ni \& Laporte, 1995). Therefore, we suggest that the interaction of the predominant STRE with Msn2p/Msn4p requires other undefined cisor trans-acting elements to confer a relative specificity of the transcriptional response of genes involved in glycogen and trehalose metabolism as compared to CTT1 and perhaps other STRE-regulated genes.

The expression of SSA3, encoding a protein of the Hsp70 family, has been shown to be dependent on two cis-acting elements: a typical HSE and a specific upstream activating sequence named $\mathrm{UAS}_{\mathrm{PDS}}$ (Boorstein \& Craig, 1990). This latter element has been considered to be a variant of STRE, and hence SSA3 is thought to be a STRE-regulated gene (Ruis \& Schüller, 1995; Winderickx et al., 1996). The fact that SSA3 does not respond to osmotic shock (Winderickx et al., 1996) and is still induced at temperature above $40{ }^{\circ} \mathrm{C}$ (see below) suggests that SSA3 is not a STRE-regulated gene.

Another aspect of this work was to show that the transcriptional induction of genes was not accompanied by a corresponding accumulation of these reserve carbohydrates. However, experiments with mutants defective in MSN2/MSN4 indicated that the increase in glycogen and the transient rise of trehalose upon a temperature shift ranging from 33 to $37^{\circ} \mathrm{C}$, or after a salt shock, required the transcriptional activation of GSY2 and TPS1. A likely explanation for the lack of correlation between transcriptional induction and accumulation of reserve carbohydrates is that both biosynthesis and biodegradation pathways are activated almost to the same extent. As a consequence, a major effect of stress was to drastically stimulate a recycling of glycogen and trehalose molecules instead of favouring their accumulation. For instance, it can be calculated that in yeast cells incubated at $37^{\circ} \mathrm{C}$, recycling of glycogen and trehalose amounts to about $10 \mu \mathrm{mol}$ glucose $\min ^{-1}$ (g dry weight $)^{-1}$. This assertion mainly rests on experiments performed with mutants defective in the key enzymes catalysing the degradation of glycogen and trehalose, and it is consistent with the previous demonstration that heat shock induced a futile cycling of trehalose (Hottiger et al., 1987). It could be interesting to quantify more precisely this cycling under various types of stress using pulse-chase experiments. Because this recycling of molecules resulted in ATP hydrolysis, the physiological significance of this wasteful expenditure of energy induced by stress needs to be clarified. Also, the fact that the accumulation of glycogen upon salt stress was cancelled by deletion of GPH1 is puzzling and adds more complexity to the already unclear function of this polymer in yeast.

Some previous workers seeking to understand the mechanism by which heat shock induced the accumulation of trehalose argued that the induction of expression of TPS1 was an essential key in this process (Hottiger et al., 1987; Bell et al., 1992), while others suggested that this rapid accumulation primarily resulted from the direct effect of temperature on the kinetic properties of Tre6P synthase complex and trehalase (Neves \& François, 1992; Londesborough \& Vuorio, 1993). Here, we showed that both gene induction and temperature modulation of kinetic properties of trehalose enzymes takes part in this process, but their relative involvement is strongly linked to the temperature range at which heat shocks are performed. Within temperature upshifts between 33 and $37^{\circ} \mathrm{C}$, the transcriptional activation of TPS1 was needed to allow a net, but otherwise transient, accumulation of trehalose. Between 37 and $40^{\circ} \mathrm{C}$, small changes in the absolute temperature resulted in a strong reduction of TPS1 expression, but in great changes of kinetic properties of Tre6P synthase/phosphatase complex and trehalase. However, it seems that transcriptional activation of TPS1 is still needed for optimal trehalose accumulation in this range of temperatures because experiments performed with either a thermosensitive mutant deficient in protein synthesis (De Virgilio et al., 1991) or in the presence of cycloheximide, an unspecific protein synthesis inhibitor (Panek et al., 1990; Neves \& François, 1992; Lewis et al., 1995), showed a lower accumulation of trehalose.

At temperatures above $40^{\circ} \mathrm{C}$, induction of STREregulated genes was abolished, while trehalose accumulated to very high levels. The capacity of cells to accumulate high levels of trehalose seems to be linked to the amount of Tre6P synthase they contain before the stress. In favour of this, an $m s n 2 / m s n 4$ double mutant accumulated less trehalose at $42^{\circ} \mathrm{C}$ than the isogenic wild-type because the basal expression of TPS1, and thus the activity of Tre6P synthase, was reduced. As a conclusion, the fact that the most efficient accumulation 
of trehalose occurred above $40^{\circ} \mathrm{C}$ is a nice illustration of the in vivo function of the high temperature-dependence of Tre6P synthase activity reported by Londesborough \& Vuorio (1993). Moreover, assuming that trehalose is a major component for yeast thermotolerance (De Virgilio et al., 1991, 1994; Attfield et al., 1994; Piper, 1995), this peculiarity of Tre6P synthase is likely to be an evolutionary adaptation of yeast to produce trehalose under conditions which are otherwise inhibitory for the STRE-dependent transcriptional machinery.

\section{ACKNOWLEDGEMENTS}

We are indebted to P. K. Hwang (UCSF, USA), K. Tatchell (Shreveport, USA), T. Hardy (Indianapolis, USA), H. Holzer (Freiburg, Germany), F. Estruch (Valencia, Spain) and C. Gancedo and M. A. Blazquez (Madrid, Spain) for the gift of yeast strains and plasmids and to J. Londesborough (Helsinki, Finland) for providing anti-(Tre6P synthase complex) KH1142 antibodies. We also thank Professor H. Terenzi (São Paulo, Brazil) for carrying out initial glycogen synthase and glycogen phosphorylase measurements. This work was supported in part by the Commission of the European Union (programme Cell Factories no. BIO4.CT95.132). J.L.P. holds a fellowship from the Ministère de la Recherche et de l'Enseignement Supérieur.

\section{REFERENCES}

Alizadeh, P. \& Klionsky, D. J. (1996). Purification and biochemical characterization of the ATH1 gene product, vacuolar acid trehalase, from Saccharomyces cerevisiae. FEBS Lett 391, 273-278.

Attfield, P. V., Kletsas, S. \& Hazell, B. W. (1994). Concomitant appearance of intrinsic thermotolerance and storage of trehalose in Saccharomyces cerevisiae during early respiratory phase of batch-culture is CIF1-dependent. Microbiology 140, 2625-2632.

Becker, J. U. (1978). A method for glycogen determination in whole yeast cells. Anal Biochem 86, 56-64.

Bell, W., Klaassen, P., Ohnacker, M., Boller, T., Herweijer, M., Schoppink, P., Van Der Zee, P. \& Wiemken, A. (1992). Characterization of the $56-\mathrm{kDa}$ subunit of yeast trehalose- 6 -phosphate synthase and cloning of its gene reveal its identity with the product of $C I F 1$, a regulator of carbon catabolite inactivation. Eur J Biochem 209, 951-959.

Boorstein, W. R. \& Craig, E. A. (1990). Regulation of a yeast $H S P 70$ gene by a cAMP responsive transcriptional control element. EMBO J 9, 2543-2553.

Bradford, M. M. (1976). A rapid and sensitive method for the quantitation of microgram quantities of protein utilizing the principle of protein dye binding. Anal Biochem 72, 248-254.

Cheng, C., Mu, J., Farkas, I., Huang, D., Goebl, M. G. \& Roach, P. J. (1995). Requirement of the self-glucosylating initiator proteins Glg1p and Glg2p for glycogen accumulation in Saccharomyces cerevisiae. Mol Cell Biochem 15, 6632-6640.

Destruelle, M., Holzer, H. \& Klionsky, D. J. (1995). Isolation and characterization of a novel yeast gene, ATH1, that is required for vacuolar acid trehalase activity. Yeast 11, 1015-1025.

De Virgilio, C., Piper, P., Boller, T. \& Wiemken, A. (1991). Acquisition of thermotolerance in Saccharomyces cerevisiae without heat shock protein hsp104 and in the absence of protein synthesis. FEBS Lett 288, 86-90.

De Virgilio, C., Bürckert, N., Bell, W., Jenö, P., Boller, T. \& Wiemken, A. (1993). Disruption of TPS2, the gene encoding the
$100-\mathrm{kDa}$ subunit of the trehalose-6-phosphate synthase/ phosphatase complex in Saccharomyces cerevisiae, causes accumulation of trehalose-6-phosphate and loss of trehalose-6phosphate phosphatase activity. Eur J Biochem 212, 315-323.

De Virgilio, C., Hottiger, T., Dominguez, T., Boller, T. \& Wiemken, A. (1994). The role of trehalose synthesis for the acquisition of thermotolerance in yeast. I. Genetic evidence that trehalose is a thermoprotectant. Eur J Biochem 219, 179-186.

Farkas, I., Hardy, T. A., Goebl, M. G. \& Roach, P. J. (1991). Two glycogen synthase isoforms in Saccharomyces cerevisiae are coded by distinct genes that are differentially controlled. J Biol Chem 266, 15602-15607.

François, J., Villanueva, M. E. \& Hers, H. G. (1988). The control of glycogen metabolism in yeast. I. Interconversion in vivo of glycogen synthase and glycogen phosphorylase induced by glucose, a nitrogen source or uncouplers. Eur J Biochem 174, 551-559.

François, J., Thompson-Jaeger, J. S., Zellenka, U., Spevak, W. \& Tatchell, K. (1992). Gac1 may encode a regulatory subunit for protein phosphatase type 1 in Saccharomyces cerevisiae. EMBO J 11, 87-96.

François, J., Blazquez, M. A., Ariño, J. \& Gancedo, C. (1997). Storage carbohydrates in the yeast Saccharomyces cerevisiae. In Yeast Sugar Metabolism, pp. 285-311. Edited by F. K. Zimmermann. Lancaster, PA: Technomics Publishing.

Gounalaki, N. \& Thireos, G. (1994). Yap1p, a yeast transcriptional activator that mediates multidrug resistance, regulates the metabolic stress response. EMBO J 13, 4036-4041.

Hottiger, T., Schmutz, P. \& Wiemken, A. (1987). Heat-induced accumulation and futile cycling of trehalose in Saccharomyces cerevisiae. J Bacteriol 169, 5518-5522.

Hwang, P. K., Tugendreich, S. \& Fletterick, R. J. (1989). Molecular analysis of GPH1, the gene encoding glycogen phosphorylase in Saccharomyces cerevisiae. Mol Cell Biol 9, 1659-1666.

Kobayashi, N. \& McEntee, K. (1990). Evidence for a heat shock factor-independent mechanism for heat shock induction of transcription in Saccharomyces cerevisiae. Proc Natl Acad Sci, USA 87, 6550-6554.

Kobayashi, N. \& McEntee, K. (1993). Identification of $c$ is and trans components of a novel heat shock stress regulatory pathway in Saccharomyces cerevisiae. Mol Cell Biol 13, 248-256.

Kopp, M., Müller, H. \& Holzer, H. (1993). Molecular analysis of the neutral trehalase gene from Saccharomyces cerevisiae. J Biol Chem 268, 4766-4774.

Lewis, L. G., Learmonth, R. P. \& Watson, K. (1995). Induction of heat, freezing and salt tolerance by heat and salt shock in Saccharomyces cerevisiae. Microbiology 141, 687-694.

Lillie, S. H. \& Pringle, J. R. (1980). Reserve carbohydrate metabolism in Saccharomyces cerevisiae: responses to nutrient limitation. J Bacteriol 143, 1384-1394.

Londesborough, J. \& Vuorio, O. E. (1993). Purification of trehalose synthase from baker's yeast. Its temperature-dependent activation by fructose-6-phosphate and inhibition by phosphate. Eur J Biochem 216, 841-848.

Mager, W. H. \& de Kruijff, A. J. J. (1995). Stress-induced transcriptional activation. Microbiol Rev 59, 506-531.

Marchler, G., Schüller, C., Adam, G. \& Ruis, H. (1993). The Saccharomyces cerevisiae UAS element controlled by protein kinase A activates transcription in response to a variety of stress conditions. EMBO J 12, 1997-2003.

Martinez-Pastor, M. T., Marchler, G., Schüller, C., Marchler-Bauer, A., Ruis, H. \& Estruch, F. (1996). The Saccharomyces cerevisiae 
zinc finger proteins $M s n 2 p$ and Msn4p are required for transcriptional induction through the stress-response element (STRE). EMBO J 15, 2227-2235.

Myers, A. M., Tzagaloff, A., Kinney, D. M. \& Lusty, C. J. (1986). Yeast shuttle and integrative vectors with multiple cloning sites suitable for construction of lacZ fusions. Gene 45, 299-310.

Neves, M. J. \& François, J. (1992). On the mechanism by which a heat shock induces trehalose accumulation in Saccharomyces cerevisiae. Biochem J 288, 859-864.

Ni, H.-T. \& Laporte, D. (1995). Response of a yeast glycogen synthase gene to stress. Mol Microbiol 16, 1197-1205.

Nwaka, S., Mechler, B., Destruelle, M. \& Holzer, H. (1995), Phenotypic features of trehalase mutants in Saccharomyces cerevisiae. FEBS Lett 360, 286-290.

Orr-Weaver, T. L., Szostak, J. \& Rothstein, R. (1983). Genetic applications of yeast transformation with linear and gapped plasmids. Methods Enzymol 101, 228-245.

Panek, A. C., Vania, J. J., Paschoalin, M. F. \& Panek, D. (1990). Regulation of trehalose metabolism in Saccharomyces cerevisiae mutants during temperature shifts. Biochimie 72, 77-79.

Piper, P. W. (1995). The heat shock and ethanol stress responses of yeast exhibit extensive similarity and functional overlap. FEMS Microbiol Lett 134, 121-127.

Rose, M. \& Botstein, D. (1983). Construction and use of gene fusions lacZ ( $\beta$-galactosidase) which are expressed in yeast. Methods Enzymol 101, 167-180.

Rose, M., Winston, F. \& Hieter, P. (1990). Methods in Yeast Genetics: a Laboratory Course Manual. Cold Spring Harbor, NY: Cold Spring Harbor Laboratory.

Rowen, D. W., Meinke, M. \& LaPorte, D. C. (1992). GLC3 and GHA1 of Saccharomyces cerevisiae are allelic and encode the glycogen branching enzyme. Mol Biol Cell 12, 22-29.

Ruis, H. \& Schüller, C. (1995). Stress signaling in yeast. Bioessays 17, 959-965.

Schiestl, R. H. \& Gietz, R. D. (1989). High efficiency transformation of intact yeast cells using single stranded nucleic acids as a carrier. Curr Genet 16, 339-346.
Schüller, C., Brewster, J. L., Alexander, M. R., Gustin, M. C. \& Ruis, H. (1994). The HOG pathway controls osmotic regulation of transcription via stress response element (STRE) of the Saccharomyces cerevisiae CTT1 gene. EMBO J 13, 4382-4389.

Tabata, S. \& Hizukuri, S. (1992). Properties of yeast debranching enzyme and its specificity toward branched cyclodextrins. Eur $J$ Biochem 206, 345-348.

Thon, V. J., Vigneron-Lesens, C., Marianne-Pepin, T., Montreuil, J., Decq, A., Rachez, C., Ball, S. G. \& Cannon, J. F. (1992). Coordinate regulation of glycogen metabolism in the yeast Saccharomyces cerevisiae. J Biol Chem 267, 15224-15228.

Vandercammen, A., François, J. M., Torres, B. B., Maia, J. C. C. \& Hers, H.-G. (1989). Fructose 2,6-bisphosphate and carbohydrate metabolism during the life cycle of the aquatic fungus Blastocladiella emersonii. J Gen Microbiol 136, 137-146.

Varela, J. C. S. \& Mager, W. H. (1996). Response of Saccharomyces cerevisiae to changes in external osmolarity. Microbiology 142, 721-731.

Varela, J. C. S., Praekelt, U. M., Meacock, P. A., Planta, R. J. \& Mager, W. H. (1995). The Saccharomyces cerevisiae HSP12 gene is activated by the high-osmolarity glycerol pathway and negatively regulated by protein kinase A. Mol Cell Biol 15, 6232-6245.

Vuorio, O. E., Kalkinen, N. \& Londesborough, J. (1993). Cloning of two related genes encoding the $56-\mathrm{kDa}$ and $123-\mathrm{kDa}$ subunits of the trehalose synthase from the yeast Saccharomyces cerevisiae. Eur J Biochem 216, 849-861.

Winderickx, J., De Winde, J. H., Crauwels, M., Hino, A., Hohmann, S., Van Dijck, P. \& Thevelein, J. M. (1996). Regulation of genes encoding subunits of the trehalose synthase complex in Saccharomyces cerevisiae: novel variations of STRE-mediated transcription control? Mol Gen Genet 252, 470-482.

Winkler, K., Kienle, I., Burget, M., Wagner, J. C. \& Holzer, H. (1991). Metabolic regulation of the trehalose content of vegetative yeast. FEBS Lett 291, 269-272.

Received 15 November 1996; revised 20 January 1997; accepted 28 January 1997. 